Journal Article

\title{
The Psychological Type Profile of Readers in the Church of England: Clones of the Clergy or Distinctive Voices?
}

Francis, L.J., Jones, S.H. and Robbins, M.

This article is published by Cambridge University Press. The definitive version of this article is available at:

http://journals. cambridge.org/action/displayAbstract?fromPage=online\&aid=9358138\&filel $\mathrm{d}=\mathrm{S} 1740355313000077$

Recommended citation:

Francis, L.J., Jones, S.H. and Robbins, M. (2014), 'The Psychological Type Profile of Readers in the Church of England: Clones of the Clergy or Distinctive Voices?', Journal of Anglican Studies, Vol.12, No.2, pp.165-184. doi: 10.1017/S1740355313000077 
The Psychological Type profile of Readers in the Church of England: clones of the clergy or distinctive voices?

Leslie J Francis *

Warwick University

Susan H Jones

Glyndŵr University

Mandy Robbins

Warwick University

Author note:

*Corresponding author:

Leslie J Francis

Warwick Religions \& Education Research Unit

Institute of Education

The University of Warwick

Coventry CV4 7AL United Kingdom

Tel: $\quad+44(0) 2476522539$

Fax: $\quad$ +44 (0)2476572638

Email: leslie.francis@warwick.ac.uk 


\begin{abstract}
The present study employs Jungian psychological type theory to examine the profile of 236 Readers serving in the Church of England (108 males and 128 females) alongside previously published data providing the psychological type profile of clergy serving within the Church of England (626 men and 237 women). The analysis was interpreted to test two competing accounts of Reader ministry: that Reader ministry expresses similar qualities to those reflected in ordained ministry, and that Reader ministry represents a pioneer ministry on the boundaries of the church. Overall the findings demonstrate significant psychological similarities between those exercising Reader ministry and those exercising ordained ministry, suggesting that, in the current generation, Readers tend to present themselves as clones of the clergy rather than as distinctive voices equipped for pioneer ministry or for fresh expressions of church.
\end{abstract}

Keywords: Ministry, psychology, religion, Readers, clergy, Anglican. 
The history and development of Reader Ministry within the Church of England has been documented by a series of commentators, including King (1973), Lawton (1989), and Hiscox (1991). The order was revived at a meeting of Archbishops and Bishops at Lambeth Palace on Ascension Day 1866, largely as a means to extend the effectiveness of the traditional parochial system to new pioneering work on the boundaries between church and world. From that point onwards the role of the Reader has evolved to mirror much more closely the liturgical role of the clergy. In 1941 Readers were allowed to read the epistle, but not the gospel, to administer the chalice but not the paten, and to preach at Morning and Evening prayer, but not at Holy Communion. In 1969 Readers were authorised to read the gospel and to preach at Holy Communion. In 1969 the ministry was extended to women as well as to men.

Comparisons between the figures for $1959 / 1960$ published by the Church of England (1962) and the figures for 2006 published by the Church of England (2007) demonstrate the increasing significance of Reader ministry over this period. In 1959/1960 there were 6,452 licensed Readers; by 2006 the number of licensed Readers had increased to 8,013 with a further 2,207 Readers with permission to officiate and active emeriti. During the same period the number of licensed stipendiary clergy had fallen from 15,582 to 8,988 and the number of licensed non-stipendiary clergy (including ordained local ministers) had risen from 287 to 3,011 .

The crucial question raised by the development and expansion of Reader ministry concerns the extent to which this remains a distinctive ministry with distinctive potential, or whether it is simply the extension of significant components of ordained ministry to authorise lay people. The service for the admission and licensing of Readers approved in 2006, provided the following words of commission. 
Readers are called to serve the Church of God and to work together with clergy and other ministers. They are to lead public worship, to preach and teach the word of God, to assist at the eucharist and to share in pastoral and evangelistic work. As authorised lay ministers they are to encourage the ministries of all God's people, as the Spirit distributes gifts among us all. They are called to help the whole church to participate in God's mission to the world.

In many ways this commission is not dissimilar from the commission provided by the ordinal for the ordination to priesthood, except for the authority of eucharistic presidency and of the absolution of sins. The view that Reader ministry may be designed primarily to supplement ordained ministry is conveyed (perhaps unintentionally) in several recent texts designed to foster vocations as Readers, as evidenced by the collection of essays, subtitled Reader Ministry Today edited by Kuhrt and Nappin (2002) or by the volume, titled Reader Ministry Explored, written by Rowling and Gooder (2009).

The recent report, Reader Upbeat, published by the Church of England (2008) celebrates the 'vital and outstanding' contribution of Readers to the life and ministry of the Church of England since the reintroduction of the ministry in 1866, and argues that 'this is an important time' for Reader ministry to be strengthened and given clear and new directions. This report both emphasises the distinctiveness of Reader ministry and also the continuities with ordained ministry. On the one hand, the case is argued that there are 'new opportunities on the boundary of the church' that Readers are uniquely positioned to grasp, given their status as theologically trained and articulate lay people fully involved with the issues of working life, voluntary work, leisure and relationships. Accordingly, it is envisaged that Readers will take up a great variety of chaplaincy work, forge new opportunities for the public presence of the church, and be active in 'fresh expressions' of church. On the other hand, Reader Upbeat argues for a closer continuity between Reader ministry and the ministry 
exercised by ordained clergy. The recommendations include the possible appointment of a Reader as Reader-in-Charge of a congregation, and the possible appointment of a Reader to a House-for-Duty post. Another recommendation strengthens the view of Reader as a transitional ministry, leading 'to the vocational diaconate or to the priesthood.'

The tension between conceptualising Reader ministry as a distinctive pioneering ministry and conceptualising Reader ministry as continuous with established ordained ministry can be tested against established theoretical and empirical frameworks concerned with the psychology of ministry and rooted in personality theory and research. A considerable body of data has been assembled over the past two decades documenting the personality profile of Anglican clergy, drawing attention to the significant difference between the personality profile of clergy and of the general population and discerning the potential strengths and weaknesses of the clergy personality profile. Put crudely, if in the current generation serving Readers are largely clones of the clergy, we might expect close similarities between the personality profile of Readers and the personality profiles of clergy. If, however, Reader ministry is recruiting candidates capable of extending the scope of authorised ministry, building bridges with the unchurched and equipped to pioneer fresh expressions of church, we might expect some significant differences between the personality profile of Readers and the personality profile of clergy.

Within the broad field of personality psychology, three main models have been applied among Anglican clergy serving in England. The application of Eysenck's dimensional model of personality among Anglican ordinands, as proposed by Eysenck and Eysenck (1964), and subsequently extended by Eysenck and Eysenck (1975), was first reported by Towler and Coxon (1971) in their classic study, The Fate of the Anglican Clergy. Subsequent studies using Eysenck's dimensional model among Anglican ordinands and clergy were reported by Francis (1991), Francis and Rodger (1994a, 1994b), Francis and 
Robbins (1996), Robbins, Francis, and Rutledge (1997), Francis Robbins, Jackson, and Jones (2000), Francis, Jones, Jackson, and Robbins (2001), Francis, Jones, Robbins, and Jackson (2003), and Francis, Jackson, and Jones (2005).

Cattell's Sixteen Personality Factor Model, as proposed by Cattell, Eber and Tatsuoka (1970) and subsequently developed by Cattell, Cattell, and Cattell (1993) was for a while used quite extensively in programmes of clergy formation by the Edward King Institute and subsequently subjected to scrutiny in a sequence of research papers by David Musson (Musson 1998, 2001, 2002; Francis \& Musson, 1999; Musson \& Francis, 2000, 2002).

The model of psychological type, as proposed originally by Jung (1971) and developed through a series of instruments like the Myers-Briggs Type Indicator (Myers \& McCaulley, 1985) and the Kiersey Temperament Sorter (Kiersey and Bates, 1978) has also been used quite extensively in programmes of clergy formation, as evidenced by Goldsmith and Wharton (1993). More recently a series of studies has reported on the psychological type profile of Anglican clergymen and clergywomen both in Wales (Francis, Payne, \& Jones, 2001; Francis, Littler, \& Robbins, in press) and in England (Francis, Craig, Whinney, Tilley, \& Slater, 2007; Francis, Robbins, Duncan, Whinney, \& Ross, in press).

Within the broad field of personality psychology, so far only one study has focused on Readers in the Church of England. In this pioneering study, Musson, Hammersley and Francis (2000) employed Cattell's Sixteen Personality Factory Model, as proposed by Cattell, Eber and Tatsuoka (1970), among a sample of 57 male trainee readers and 75 female trainee readers from six Anglican dioceses of central England. The profiles of these male and female trainee readers were then compared with the profiles of Anglican clergymen $(\mathrm{N}=441)$ and clergywomen $(\mathrm{N}=55)$ published by Musson (1998). The data demonstrated that male trainee readers differed from clergymen in terms of ten of the sixteen personality factors and that female trainee readers differed from clergywomen in terms of five of the sixteen personality 
factors. The three main limitations with this study concern the facts that is based on trainee readers (rather than experienced readers), that the comparisons are based on small numbers (only 57 male trainee readers and 55 clergywomen), and that the Cattell model of personality may not be the most productive model with which to compare the profiles of clergy and Readers.

Against this background, the aim of the present study is to build on Musson, Hammersley and Francis' (2000) work by drawing on a larger sample of experienced Readers, by employing the model of psychological type, as originally proposed by Jung (1971), and by situating these new data alongside the authoritative survey of 237 clergywomen and 626 clergymen serving in the Church of England published by Francis, Craig, Whinney, Tilley and Slater (2007). Jung's model of psychological type offers a particularly productive lens through which to study those involved in religious ministry for two main reasons. First, the four main psychological constructs utilised and operationalised by the theory map particularly powerfully onto areas of relevance for individual differences in terms of both religious expression and of ministry practice (see Francis, 2009). Second, in recent years a considerably body of data has been assembled to enable comparisons to be formulated between individuals engaged in different forms of ministry and within different denominational contexts. These studies include Presbyterian Church of Scotland ministers (Irvine, 1989), Bible College students (Francis, Penson, \& Jones, 2001), evangelical church leaders (Francis \& Robbins, 2002; Craig, Francis, \& Robbins, 2004), missionary personal (Craig, Horsfall, \& Francis, 2005), evangelical lay church leaders (Francis, Craig, Horsfall, \& Ross, 2005), Roman Catholic priests (Craig, Duncan, \& Francis, 2006), youth ministers (Francis, Nash, Nash, \& Craig, 2007), evangelical Anglican seminarians (Francis, Craig, \& Butler, 2007), Assemblies of God theological college students (Kay, Francis, \& Craig, 2008; Kay \& Francis, 2008), leaders within the Newfrontiers network of churches (Francis, Gubb, 
\& Robbins, 2009; Ryland, Francis, \& Robbins, in press), Anglican clergy serving in Wales (Francis, Payne, \& Jones, 2001; Francis, Littler, \& Robbins, in press), Anglican clergy serving in England (Francis, Craig, Whinney, Tilley, \& Slater, 2007; Francis, Robbins, Duncan, Whinney, \& Ross, in press), and leaders within the Apostolic network of churches (Kay, Francis, \& Robbins, in press).

As popularised through books like Gifts differing (Myers \& Myers, 1980, psychological type theory distinguishes between four bipolar psychological perspectives: two orientations (introversion and extraversion), two perceiving functions (sensing and intuition), two judging functions (thinking and feeling), and two attitudes toward the outer world (judging and perceiving). According to this model, the two orientations (introversion and extraversion) and the two attitudes (judging and perceiving) define the kind of context within which the individual human psyche functions. The two perceiving functions (sensing and intuition) and the two judging functions (thinking and feeling) define the mental processes involved in interpreting and making sense of the world.

The two orientations are concerned with where energy is drawn from and focused. On the one hand, extraverts (E) are orientated toward the outer world; they are energised by the events and people around them. They enjoy communicating and thrive in stimulating and exciting environments. They tend to focus their attention upon what is happening outside themselves. They are usually open people, easy to get to know, and enjoy having many friends. On the other hand, introverts (I) are orientated toward their inner world; they are energised by their inner ideas and concepts. They enjoy solitude, silence, and contemplation, as they tend to focus their attention on what is happening in their inner life. They may prefer to have a small circle of intimate friends rather than many acquaintances.

The two perceiving functions are concerned with the way in which people perceive information. On the one hand, sensing types (S) focus on the realities of a situation as 
perceived by the senses. They tend to focus on specific details, rather than the overall picture. They are concerned with the actual, the real, and the practical and tend to be down to earth and matter of fact. On the other hand, intuitive types $(\mathrm{N})$ focus on the possibilities of a situation, perceiving meanings and relationships. They may feel that perception by the senses is not as valuable as information gained as indirect associations and concepts impact on their perception. They focus on the overall picture, rather than on specific facts and data.

The two judging functions are concerned with the criteria which people employ to make decisions and judgements. On the one hand, thinking types (T) make decisions and judgements based on objective, impersonal logic. They value integrity and justice. They are known for their truthfulness and for their desire for fairness. They consider conforming to principles to be of more importance than cultivating harmony. On the other hand, feeling types $(\mathrm{F})$ make decisions and judgements based on subjective, personal values. They value compassion and mercy. They are known for their tactfulness and for their desire for peace. They are more concerned to promote harmony, than to adhere to abstract principles.

The two attitudes toward the outer world are determined by which of the two sets of functions (that is, perceiving $\mathrm{S} / \mathrm{N}$, or judging $\mathrm{T} / \mathrm{F}$ ) is preferred in dealings with the outer world. On the one hand, judging types (J) seek to order, rationalise, and structure their outer world, as they actively judge external stimuli. They enjoy routine and established patterns. They prefer to follow schedules in order to reach an established goal and may make use of lists, timetables, or diaries. They tend to be punctual, organised, and tidy. They prefer to make decisions quickly and to stick to their conclusions once made. On the other hand, perceiving types $(\mathrm{P})$ do not seek to impose order on the outer world, but are more reflective, perceptive, and open, as they passively perceive external stimuli. They have a flexible, openended approach to life. They enjoy change and spontaneity. They prefer to leave projects open in order to adapt and improve them. Their behaviour may often seem impulsive and 
unplanned.

According to Jungian theory, for each individual either the preferred perceiving function (sensing or intuition) or the preferred judging function (thinking or feeling) takes preference over the other, leading to the emergence of one dominant function which shapes the individual's dominant approach to life. Dominant sensing shapes the practical person; dominant intuition shapes the imaginative person; dominant feeling shapes the humane person; and dominant thinking shapes the analytic person. According to Jungian theory, it is the function opposite to the dominant function which is least well developed in the individual (the inferior function). Thus, the dominant senser experiences most difficulty with the intuitive function; the dominant intuitive experiences most difficulty with the sensing function; the dominant thinker experiences most difficulty with the feeling function; and the dominant feeler experiences most difficulty with the thinking function.

Francis, Craig, Whinney, Tilley, and Slater (2007) set their study of 626 clergymen and 237 clergywomen serving in the Church of England within the context of the UK population norms published by Kendall (1998). These data demonstrated that Anglican clergymen differed significantly from the general population of men in three ways. The largest difference occurred in terms of the perceiving process where $62 \%$ of the clergymen preferred intuition, compared with $27 \%$ of the male population. The second largest difference occurred in terms of the judging process where $54 \%$ of the clergymen preferred feeling, compared with $35 \%$ of the male population. The third difference occurred in terms of the attitude toward the outside world, where $68 \%$ of the clergymen preferred judging, compared with $55 \%$ of the male population. On the other hand, there were no significant differences in terms of the orientations, where $57 \%$ of the clergymen preferred introversion and so did $53 \%$ of the male population. These data also demonstrated that Anglican clergywomen differed significantly from the general population of women in two ways. The largest difference 
occurred in terms of the perceiving process, where $65 \%$ of the clergywomen preferred intuition, compared with $21 \%$ of the female population. The second difference occurred in terms of the orientations, where $54 \%$ of the clergywomen preferred introversion, compared with $43 \%$ of the female population. On the other hand, there were no significant differences in terms of the judging process (where $74 \%$ of the clergywomen preferred feeling and so did $70 \%$ of the female population) or in terms of the attitudes toward the outer world (where $65 \%$ of the clergywomen preferred judging and so did $62 \%$ of the UK female population).

In their interpretation of these data, Francis, Craig, Whinney, Tilley, and Slater (2007) drew two main forms of conclusions. The first conclusion concerned the implications of the differences between the profile of clergy and the profile of the general population among whom they ministered. In particular, they highlighted the disparity between the worldview of intuitives (so strongly represented among clergy) and the worldview of sensers (so strongly represented among the general population). The second conclusion concerned the implications of the clergy profile for the ways in which clergy conceptualise and implement their ways of doing ministry.

The present study provides the first opportunity to explore to what extent Readers share a psychological type profile in common with the clergymen and clergywomen studied by Francis, Craig, Whinney, Tilley, and Slater (2007) or to what extent Readers bring to the Anglican ministry in England a different and complementary psychological type profile to that displayed by clergy.

\section{Method}

\section{Procedure}

Over a period of time Readers participating in a range of workshops concerned with psychological type and preaching completed an established measure of psychological type and agreed as part of the progamme to their data being used for research purposes. 


\section{Instrument}

Psychological type was assessed by the Francis Psychological Type Scales (FPTS:

Francis, 2005). This 40-item instrument comprises four sets of ten forced-choice items related to each of the four components of psychological type: orientation (extraversion or introversion), perceiving process (sensing or intuition), judging process (thinking or feeling), and attitude toward the outer world (judging or perceiving). Recent studies have demonstrated this instrument to function well in church-related contexts. For example, Francis, Craig, and Hall (2008) reported alpha coefficients of .83 and for EI scale, .76 for the SN scale, .73 for the TF scale, and .79 for the JP scale.

\section{Sample}

The sample comprised 108 men and 128 women. Among the men $12 \%$ were under the age of fifty, $21 \%$ were in their fifties, $30 \%$ were in their sixties, $22 \%$ were in their seventies, and $9 \%$ were in their eighties. Among the women, $16 \%$ were under the age of fifty, $36 \%$ were in their fifties, $38 \%$ were in their sixties, and $10 \%$ were in their seventies.

\section{Data analysis}

The scientific literature concerned with psychological type has developed a distinctive way of presenting type-related data. The conventional format of 'type tables' has been used in the present paper to allow the findings from this study to be compared with other relevant studies in the literature. In these tables the psychological type profiles of the male and female Readers are compared with the psychological type profiles of Anglican clergymen and Anglican clergywomen as reported by Francis, Craig, Whinney, Tilley, and Slater (2007). The statistical significance of differences between the present sample and the population norms and the Anglican clergy are tested by means of the Selection Ratio Index (I), an extension of the classic chi-square test.

\section{Results}


The first step in the data analysis examined the internal consistency reliability of the scales from which the type categories were derived, employing the alpha coefficient (Cronbach, 1951). The following coefficients were found: extraversion and introversion, .81; sensing and intuition, .78; thinking and feeling, .71; judging and perceiving, .81 . All of these coefficients are above the threshold of .65 proposed by DeVellis (2003) and indicate that the instruments are functioning reliably among this sample.

Table 1 presents the psychological type profile of the 108 male Readers. These data demonstrate that male Readers display clear preference for itroversion (69\%) over extraversion (32\%), clear preference for sensing (62\%) over intuition (38\%), clear preference for feeling (58\%) over thinking (42\%), and clear preference for judging (81\%) over perceiving (19\%). In terms of dominant type preferences, $44 \%$ of the male Readers are dominant sensing types, $22 \%$ are dominant intuitive types, $20 \%$ are dominant feeling types, and $14 \%$ are dominant thinking types. The two most highly represented types among male Readers are ISFJ (24\%) and ISTJ(17\%).

-insert table 1 about here -

Table 2 presents the psychological type profile of the 128 female Readers. These data demonstrate that female Readers display clear preference for judging $(71 \%)$ over perceiving (29\%), clear preference for feeling (64\%) over thinking (36\%), slight preference for introversion (54\%) over extraversion (46\%), and a balance between sensing (50\%) and intuition (50\%). In terms of dominant type preferences, $34 \%$ of the female Readers are dominant sensing types, $27 \%$ are dominant intuitive types, $27 \%$ are dominant feeling types, and $13 \%$ are dominant thinking types. The four most highly represented types are ISFJ (13\%), ISTJ (13\%), ESFJ (13\%), and INFJ (12\%).

-insert table 2 about here -

Table 1 takes the analysis one step further by testing the psychological type profile of 
male Readers against the type profile for clergymen in the Church of England published by Francis, Craig, Whinney, Tilley, and Slater (2007). In terms of the binary distinctions, these data demonstrate: that male Readers are significantly less inclined than clergymen to prefer intuition (38\% compared with $62 \%$ ); that male Readers are significantly more inclined than clergymen to prefer judging ( $81 \%$ compared with $68 \%$ ); that male Readers are significantly more inclined than clergymen to prefer introversion (69\% compared with $57 \%$ ); and that there is no significant difference between male Readers and clergymen in terms of preference for feeling ( $58 \%$ and $54 \%$ respectively). In terms of dominant type preferences, the main significant difference between male Readers and clergymen occurs in respect of the dominant sensing category: while $44 \%$ of male Readers prefer dominant sensing, the proportion stands at $21 \%$ among clergymen. Two other striking differences emerge between the male Readers and the clergymen reflecting their differential preferences for sensing and intuition. While the type ISFJ accounts for $24 \%$ of the male Readers, this type accounts for just $9 \%$ of the clergymen. While the temperament SJ accounts for $56 \%$ of the male Readers, this temperament accounts for $31 \%$ of the clergymen.

Table 2 also takes the analysis one step further by testing the psychological type profile of female Readers against the type profile for clergywomen in the Church of England published by Francis, Craig, Whinney, Tilley, and Slater (2007). In terms of the binary distinctions, these data demonstrate: that female Readers are significantly less inclined than clergywomen to prefer intuition ( $50 \%$ compared with $65 \%$ ); that female Readers are significantly less inclined that clergywomen to prefer feeling (65\% compared with $74 \%$ ); that there is no significant difference between female Readers and clergywomen in terms of preference for introversion ( $54 \%$ and 54\% respectively); and that there is no significant difference between female Readers and clergywomen in terms of preference for judging ( $71 \%$ and $65 \%$ respectively). In terms of dominant type preferences, the two significant 
differences between female Readers and clergywomen occur in respect of dominant sensing and dominant feeling: while $34 \%$ of female Readers prefer dominant sensing, the proportion stands at $19 \%$ among clergywomen; while $27 \%$ of female Readers prefer dominant feeling, the proportion stands at $39 \%$ among clergywomen. In terms of temperament, compared with clergywomen the NF temperament is significantly less evident among female Readers (32\% compared with $50 \%$ ) and the SJ temperament is significantly more evident among female Readers (39\% compared with $29 \%$ ).

\section{Discussion and conclusion}

The present study set out to examine the psychological type profiles of a sample of 236 experienced Readers within the Church of England (108 and 128 women) and to compare these data with the psychological type profiles of a sample of 863 clergy within the Church of England (626 men and 237 women) published by Francis, Craig, Whinney, Tilley and Slater (2007). The rationale underpinning the project suggested that evidence of this nature could explore the tension apparent in the recent report, Reader Upbeat (Church of England, 2008), between conceptualising Reader ministry as a distinctive pioneering ministry and conceptualising Reader ministry as continuous with established ordained ministry. The notion was advanced that, if in the current generation serving Readers are largely clones of the clergy, we might expect close similarities between the psychological type profile of Readers and the psychological type profile of clergy. If, however, Reader ministry is recruiting candidates capable of extending the scope of authorised ministry, building bridges with the unchurched and equipped to pioneer fresh expressions of church, we might expect some significant differences between the psychological type profile of Readers and the psychological type profile of clergy. Four main conclusions emerge from these new data.

The first conclusion concerns the orientations, the distinction between introversion and extraversion. In their study of Anglican clergy, Francis, Craig, Whinney, Tilley and 
Slater (2007) found that female clergy preferred introversion significantly more frequently than the female United Kingdom population norms (54\% compared with 43\%). They concluded that there is a danger that the wider female population may view female clergy as somewhat withdrawn, aloof, and disengaged from society. Within the framework of psychological type theory, there may be the need for pioneer ministry to complement the profile of female clergy with a stronger preference for extravasion. The present study, however, demonstrates that female Readers closely mirror the preference for introversion displayed by female clergy (54\%).

Among male clergy, Francis, Craig, Whinney, Tilley and Slater (2007) also found a preference for introversion (57\%), although not significantly higher than that recorded by the UK male population (53\%). This preference for introversion among male Readers is, however, significantly more pronounced than is the case among male clergy $(69 \%$ compared with $57 \%$ ). In terms of the two orientations, Readers emerge as more like clergy clones than like pioneer ministers.

The second conclusion concerns the perceiving functions, the distinction between sensing and intuition. In their study of Anglican clergy, Francis, Craig, Whinney, Tilley and Slater (2007) found that both male and female clergy preferred intuition significantly more frequently than men and women in the UK population norms (female, $65 \%$ compared with $21 \%$; male, $62 \%$ compared with $27 \%$ ). They concluded that there is a danger that, given the high preference for sensing among the UK population ( $73 \%$ among males and $79 \%$ among females), the wider population may view clergy as 'dreamers', 'too heavenly minded to be any earthly good'. Within the framework of psychological type theory there may be the need for pioneer ministry to complement the profile of clergy with a stronger preference for sensing. The present study demonstrated that this is indeed the case with $62 \%$ of male Readers preferring sensing (compared with $38 \%$ of clergymen) and $50 \%$ of female Readers 
preferring sensing (compared with $35 \%$ of clergywomen). On the other hand, Readers remain less inclined to prefer sensing than is the case among the UK population, where sensing is preferred by $73 \%$ of men and by $79 \%$ of women. In terms of the two perceiving functions, Readers have some claim to be extending the personality profile of those engaged in ministry to reflect more closely the profile of the society in which they live and work.

The third conclusion concerns the judging function, the distinction between thinking and feeling. In their study of Anglican clergy, Francis, Craig, Whinney, Tilley and Slater (2007) found that male clergy preferred feeling significantly more frequently than the male UK population norms ( $54 \%$ compared with $35 \%$ ). They concluded that there is a danger that, given the higher preference in the UK population for feeling among women than among men (70\% compared with $35 \%$ ), the wider male population may view male clergy as displaying a characteristically feminine personality profile, appearing sentimental, and reluctant to handle difficult questions about beliefs and social justice. Within the framework of psychological type theory, there may be the need for pioneer ministry to complement the profile of male clergy with a stronger preference for thinking. The present study, however, demonstrates that male Readers closely mirror the preference for feeling displayed by male clergy (58\%).

Among female clergy, Francis, Craig, Whinney, Tilley and Slater (2007) also found a clear preference for feeling (74\%) although not significantly higher than that recorded by the UK female population (70\%). Female Readers, however, display a significantly lower preference for feeling than is the case among female clergy (64\% compared with $74 \%)$. The overall picture remains, nonetheless, that the profiles of male and female clergy and of male and female Readers are strongly in the direction of feeling, leaving the tougher masculine profile of thinking notably absent from the field of Anglican ministry.

The fourth conclusion concerns the attitudes toward the outer world, the distinction between judging and perceiving. In their study of Anglican clergy, Francis, Craig, Whinney, 
Tilley and Slater (2007) found that male clergy preferred judging significantly more frequently than the male UK population norms (68\% compared with 55\%). They concluded that there is a danger that the wider male population may view male clergy as rigid, inflexible, and unable to handle change or spontaneity. Within the framework of psychological type theory, there may be the need for pioneer ministry to complement the profile of male clergy with a stronger preference for perceiving. The present study, however, demonstrates that male Readers are even more inclined to prefer judging than male clergy (81\% compared with $68 \%)$.

Among female clergy, Francis, Craig, Whinney, Tilley and Slater (2007) also found a preference for judging (62\%), although not significantly different form that recorded by the UK female population (65\%). The preference for judging was of a comparable level among female Readers (71\%). The overall picture remains that the profiles of male and female clergy and of male and female Readers are strongly in the direction of judging, leaving the more flexible profile of perceiving notably absent from the field of Anglican ministry.

Taken together, these four conclusions strongly suggest that, in the current generation, the psychological type profile of serving Readers fits them more adequately to conduct a model of ministry already well established by the ordained clergy than to extend that ministry in pioneering new directions. Within the current cohort of Readers, it may be in particular the minority ( $8 \%$ of males and $18 \%$ of females) combining preferences for extraversion and for perceiving, who could find themselves in the strongest position to fulfil the vision of the report Reader Upbeat, to forge new opportunities for the public presence of the church, and to be acting in 'fresh expressions' of church.

The present study has employed psychological type theory and empirical investigation to test aspects of the potential distinctiveness of Reader ministry, compared with that of ordained clergy. A significant weakness of the present study concerns the nature of the 
sample. The conclusions are based on just 236 Readers (compared with 863 clergy), and even these 236 Readers were obtained by opportunity sampling. In order to build on the present study there is the need for a systematic survey of those engaged in Reader ministry capable both of providing a more authoritative psychological type profile and of establishing how individual differences in the psychological type preferences of Readers may lead to significant differences in the ways in which their ministry is expressed. 
Table 1

Type distribution for male Readers compared with Anglican clergymen

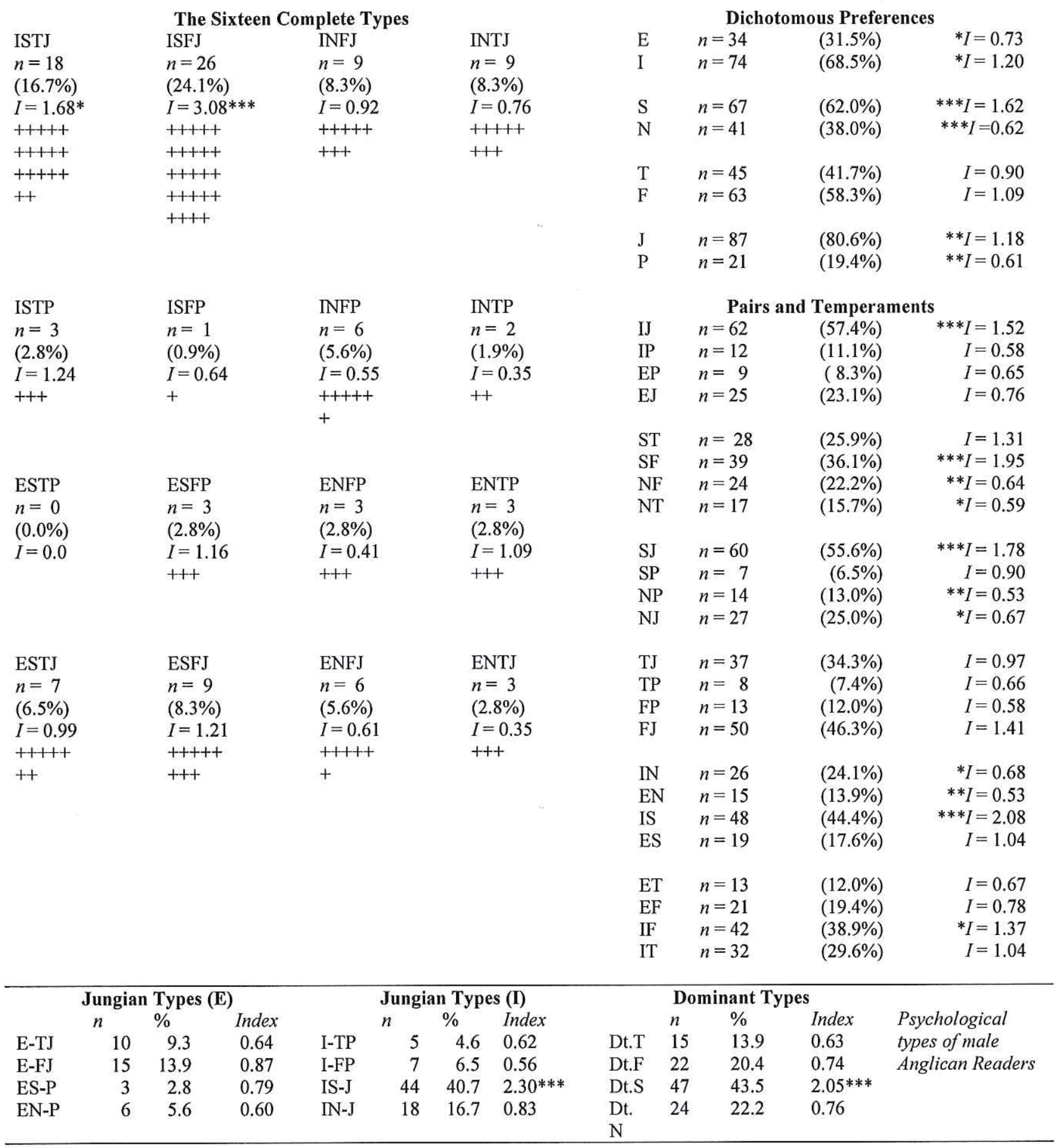

Note: $\mathrm{N}=108 \quad+=1 \%$ of $\mathrm{N} \quad * p<.05 \quad * * p<.01 \quad * * * p<.001$ 
Table 2

Type distribution for female Readers compared with Anglican clergywomen

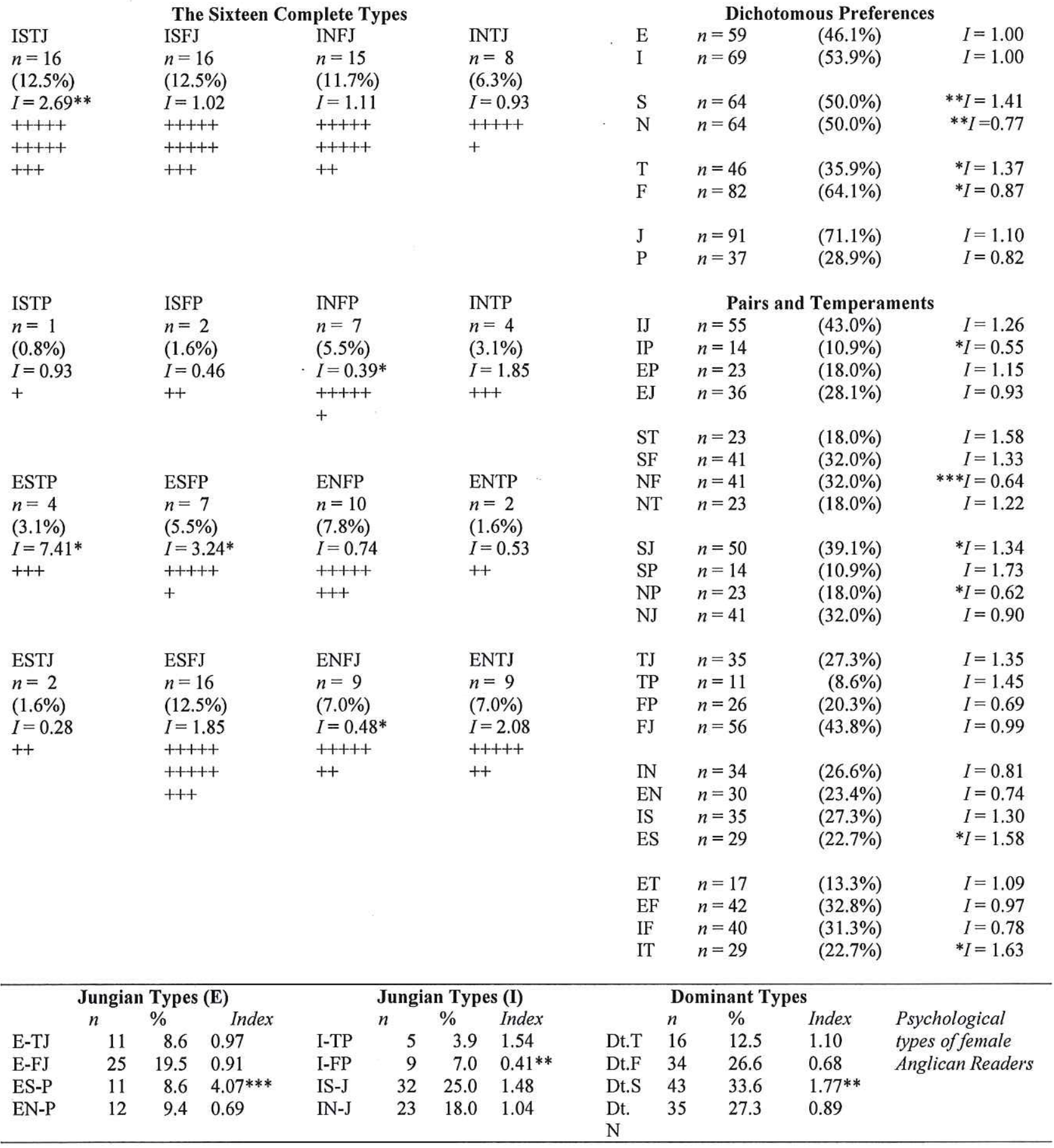

Note: $\mathrm{N}=128 \quad+=1 \%$ of $\mathrm{N} \quad * p<.05 \quad * * p<.01 \quad * * * p<.001$ 


\section{References}

Cattell, R. B., Cattell, A. K. S., \& Cattell, H. E. P. (1993). Sixteen Personality Factor Questionnaire: fifth edition (16PF5). Windsor: NFER-Nelson.

Cattell, R. B., Eber, H. W., \& Tatsuoka, M. M. (1970). Handbook for the Sixteen Personality Factor Questionnaire (16PF). Champaign, Illinois: Institute for Personality and Ability Testing.

Church of England. (1962). Facts and figures about the Church of England. London: Central Board of Finance of the Church of England.

Church of England. (2007). Church Statistics 2005/6. London: Church House Publishing. Church of England. (2008). Reader upbeat: Quickening the tempo of Reader ministry in the Church Today. London: General Synod GS1689.

Craig, C L., Duncan, B., \& Francis, L.J. (2006). Psychological type preferences of Roman Catholic priests in the United Kingdom. Journal of Beliefs and Values, 27, 157-164.

Craig, C., Francis, L.J., \& Robbins, M. (2004). Psychological type and sex differences among church leaders in the United Kingdom. Journal of Beliefs and Values, 25, 3-13.

Craig, C. L., Horsfall, T., \& Francis, L. J. (2005). Psychological types of male missionary personnel training in England: A role for thinking type men? Pastoral Psychology, 53, $475-482$.

Cronbach, L. J. (1951). Coefficient alpha and the internal structure of tests. Psychometrika, $16,297-334$.

Eysenck, H. J., \& Eysenck, S.B.G. (1964). Manual of the Eysenck Personality Inventory. London: University of London Press.

Eysenck, H. J., \& Eysenck, S. B. G. (1975). Manual of the Eysenck Personality Questionnaire (adult and junior). London: Hodder and Stoughton.

DeVellis, R. F. (2003). Scale development: Theory and applications. London: Sage. 
Francis, L. J. (1991). The personality characteristics of Anglican ordinands: feminine men and masculine women? Personality and Individual Differences, 12, 1133-1140.

Francis, L. J. (2009). Psychological type theory and religious and spiritual experience. In M. De Souza, L. J. Francis, J. O’Higgins-Norman, \& D. G. Scott (Eds.), International Handbook of education for spirituality, care and wellbeing (pp 125-146).

Francis, L.J., Craig, C.L., \& Butler, A. (2007). Psychological types of male evangelical Anglican seminarians in England. Journal of Psychological Type, 67, 11-17.

Francis, L. J., Craig, C. L., Horsfall, T., \& and Ross, C. F. J. (2005). Psychological types of male and female evangelical lay church leaders in England, compared with United Kingdom population norms. Fieldwork in Religion, 1, 69-83.

Francis, L. J., Craig, C. L., Whinney, M., Tilley, D., \& Slater, P. (2007). Psychological profiling of Anglican clergy in England: Employing Jungian typology to interpret diversity, strengths, and potential weaknesses in ministry. International Journal of Practical Theology, 11, 266-284.

Francis, L. J., Gubb, S., \& Robbins, M. (1999). Psychological type profile of Lead Elders within the Newfrontiers network of churches in the United Kingdom. Journal of Beliefs and Values, 30, 61-69.

Francis, L. J., Jackson, C. J., \& Jones, S. H. (2005). Assessing the personality of clergy: abbreviated Eysenck Personality Profiler (EPP-A). Research in the Social Significance of Religion, 15, 1-16.

Francis, L. J., Jones, S. H., Jackson, C. J., \& Robbins, M. (2001). The feminine personality profile of male Anglican clergy in Britain and Ireland: a study employing the Eysenck Personality Profiler. Review of Religious Research, 43, 14-23. 
Francis, L. J., Jones, S. H., Robbins, M., \& Jackson, C. J. (2003). The personality profile of female Anglican clergy in Britain and Ireland: a study employing the Eysenck Personality Profiler. Archiv für Religionspsychologie, 25, 222-231.

Francis, L. J., Littler, K., Robbins, M. (in press). Psychological type and Offa's Dyke: Exploring differences in the psychological type profile of Anglican clergy serving in England and Wales. Contemporary Wales.

Francis, L. J., \& Musson, D. J. (1999). Male and female Anglican clergy in England: gender reversal on the 16PF? Journal of Empirical Theology, 12(2), 5-16.

Francis, L. J., Nash, P., Nash, S., \& Craig, C.L. (2007). Psychology and youth ministry:

Psychological type preferences of Christian youth workers in the United Kingdom. Journal of Youth Ministry, 5(2), 73-90.

Francis, L. J., Payne, V. J., \& Jones, S. H. (2001). Psychological types of male Anglican clergy in Wales. Journal of Psychological Type, 56, 19-23.

Francis, L. J., Penson, A.W., \& Jones, S.H. (2001). Psychological types of male and female Bible College students in England. Mental Health, Religion and Culture, 4, 23-32.

Francis, L. J. \& Robbins, M. (1996). Differences in the personality profile of stipendiary and non-stipendiary female Anglican parochial clergy in Britain and Ireland. Contact, 119, 26-32.

Francis, L. J. \& Robbins, M. (2002). Psychological types of male evangelical church leaders. Journal of Belief and Values, 23, 217-220.

Francis, L. J. Robbins, M., Duncan, B., Whinney, M., \& Ross, C. (in press). Confirming the psychological type profile of Anglican clergymen in England: A ministry for intuitive. Nova Science.

Francis, L. J., Robbins, M., Jackson, C. J., \& Jones, S. H. (2000). Personality theory and male Anglican clergy: the EPP. Contact, 113, 27-36. 
Francis, L. J., \& Rodger, R. (1994a). The influence of personality on clergy role prioritization, role influences, conflict and dissatisfaction with ministry. Personality and Individual Differences, 16, 947-957.

Francis, L. J., \& Rodger, R. (1994b). The personality profile of Anglican clergymen. Contact $113,27-32$.

Goldsmith, W.M., \& Wharton, M. (1993). Knowing me: Knowing you. London: SPCK.

Hiscox, R. (1991). Celebrating Reader ministry: 125 years of lay ministry in the Church of England. London: Mowbray.

Irvine, A. R. (1989). Isolation and the parish ministry. Unpublished $\mathrm{PhD}$ dissertation, University of St Andrews.

Jung, C. G. (1971). Psychological types: The collected works, volume 6. London: Routledge and Kegan Paul.

Kay, W. K., \& Francis, L. J. (2008). Psychological type preferences of female Bible College students in England. Journal of Beliefs and Values, 29, 101-105.

Kay, W. K., Francis, L. J., \& Craig, C. L. (2008). Psychological type preferences of male British Assemblies of God Bible College students: Tough minded or tender hearted? Journal of the European Pentecostal Theological Association, 28, 6-20.

Kay, W. K., Francis, L. J., \& Robbins, M. (in press), A distinctive leadership for a distinctive network of churches? Psychological type theory and the apostolic networks. Journal of Pentecostal Theology.

Keirsey, D., \& Bates, M. (1978). Please understand me. Del Mar, California: Prometheus Nemesis.

King, T. G. (1973). Readers: A pioneer ministry. London: Central Readers Board.

Kuhrt, G. W., \& Nappin, P. (Eds.) (2002). Bridging the gap: Reader ministry today. London: Church House Publishing. 
Lawton, G. (1989). Reader-Preacher. London: Churchman.

Musson, D. J. (1998). The personality profile of male Anglican clergy in England: the 16PF. Personality and Individual Differences, 25, 689-698.

Musson, D. J. (2001). Male and female Anglican clergy: gender reversal on the 16PF5? Review of Religious Research, 43, 175-183.

Musson, D. J. (2002). Personality of male Anglican clergy in England: revisited using the 16PF5. Mental Health, Religion and Culture, 5, 195-206.

Musson, D. J., \& Francis, L.J. (2000). The psychometric properties of the 16PF among male Anglican clergy. Pastoral Psychology 48, 231-240.

Musson, D. J., \& Francis, L.J. (2002). A comparison of the psychometric properties of the 16PF4 and 16PF5 among male Anglican clergy. Pastoral Psychology, 50, 281-289.

Musson, D. J., Hammersley, P., \& Francis, L. J. (2000). The personality profile of male and female trainee Readers in the Church of England compared to Anglican clergy: The 16PF. Pastoral Psychology, 49, 69-80.

Myers, I. B., \& McCaulley, M. H. (1985). Manual: A guide to the development and use of the Myers-Briggs Type Indicator. Palo Alto, California: Consulting Psychologists Press.

Myers, I. B., \& Myers, P. B. (1980). Gifts differing. Palo Alto: California, Consulting Psychologists Press.

Robbins, M., Francis, L. J., \& Rutledge, C. (1997). The personality characteristics of Anglican stipendiary parochial clergy in England: gender differences revisited. Personality and Individual Differences, 23, 199-204.

Robbins, M., Littler, K., \& Francis, L. J. (in press). The personality characteristics of Anglican clergymen and clergywomen: The search for sex differences. Pastoral Psychology.

Rowling, C., \& Gooder, P. (2009). Reader ministry explained. London: SPCK. 
Ryland, A., Francis, L. J., \& Robbins, M. (in press). Called for leadership: Psychological type profile of leaders within the Newfrontiers network of churches in the United Kingdom.

Towler, R. \& Coxon, A. P. M. (1979). The Fate of the Anglican Clergy: London, Macmillan. 